\title{
A estipulação de pagamento em moeda estrangeira
}

\author{
Waldemar Ferreira
}

\author{
CAPITULO I
}

\section{A CONVENÇÃO DE PAGAMENTO EM OURO OU EM DETERMINADA ESPECIE DE MOEDA}

1. O ajuste sobre a fórma e espécie do pagamento em dinheiro - Aos contratantes sempre assistiu a faculdade de ajustar a fórma e espécie de pagamento das obrigações de que fôssem sujeitos ativos ou passivos. Era isso de seu peculiar e recíproco interêsse. Quando em dinheiro, livremente podiam determinar-lhe a espécie, fixar-lhe o montante em moeda nacional ou optar pela estrangeira.

País de longa vida colonial, de indústria e comércio incipientes, pautados pela política colonisadora metropolitana, que só lhe permitia a agricultura e a tecelagem grossa de algodão, ao emancipar-se, ha pouco mais de século, tomou lugar, no seio das nações, mercê de tremendo paradoxo histórico, empobrecido, depois de ter extraído de suas minas o ouro, que contribuiu sobremodo para o advênto do capitalismo hodiérno. Não logrou enriquecer-se. Porque não o reteve. Exportou-o em grande escala. Não entesourou siquer parle dele. Nem o aplicou no seu engrandecimento material senão no tanto quanto a propria mineração exigia.

Faziam-se os pagamentos, ainda assim, e durante muito tempo, no Brasil, em metais. O cóbre, a prata, o ouro, tinham, a despeito da evasão dêste, correnteza, mesmo na 
época da independência. As providências, tomadas pela côrte portuguêsa para aqui transplantada, não alcançaram a formação do sistêma monetário brasileiro. Natural era, dessarte, a convenção de pagamento em ouro, a despeito do alvará de 1 de setembro de 1808, em que se depara a primeira manifestação da moeda fiduciária, haver autorizado as casas de fundição a, convindo os proprietários do ouro, dar-lhes, da porção, que quizessem, em vez de barras, letras impressas, de pagamento à vista pelas juntas da Fazenda ou no real erário, as quais seriam recebidas, em todos os pagamentos à real Fazenda, como moeda corrente.

Predominava, em matéria de pagamento, a liberdade contratual, por largo tempo perdurante.

2. O pagamento das dividas comerciais em moeda metálica - Refletiu-se ela no código do comércio. Disciplinando os pagamentos mercantis, cuidou êle do em dinheiro, explicitamente. Foi no art. 431. "Se", le-se na segunda alínea dêste, "se a divida fôr em moeda metálica, na falta desta o pagamento póde ser efetuado na moeda corrente no país ao câmbio que correr no lugar e dia do vencimento; e se havendo móra o câmbio descer, ao curso que tiver no dia em que o pagamento se efetuar; salvo tendo-se estipulado expressamente que êste deverá ser feito em certa e determinada espécie e a câmbio fixo".

Licita era, portanto, a convenção do pagamento em certa e determinada moeda e a câmbio fixo, hipotese em que teria de efetuar-se qual fôra pactuado, pois se em moeda metálica ajustado, a falta desta abriria ensejo para a conversão em moeda corrente, ao câmbio do lugar e dia do vencimento. Predeterminava-se, na primeira hipotese, a importância da obrigação assumida, sem alusão a tal ou qual moeda. A espécie podia, certamente, ser porção de ouro em barra, por natureza inconversivel. Na segunda, estipulando-se o pagamento em moeda metalica, a conversão era inteiramente possivel e, de resto, prevista no texto legal. 
3. As diretrizes doutrinárias sobre estipulação de moeda - De modo diferente não o entendeu o Conselheiro LAFAYETTE. E' direito, doutrinou êle, "é direito das partes fixarem nos seus contratos a moeda e o câmbio pelo qual devem pagar as obrigações contraídas, porquanto é êste assunto do exclusivo interêsse dos contratantes, e que, portanto, póde ser por êles regulado. Este principio fundamental dos contratos acha-se expressamente consagrado no final da segunda alínea do art. 431 do código comercial nas palavras "salvo tendo-se estipulado expressamente que este (pagamento) deverá ser feito em certa e determinada espécie e a câmbio fixo". As disposições do citado art. 431 sôbre a moeda em que deve ser feito o pagamento só vigoram e têm efeito no silêncio das partes, isto é, quando não ha estipulações expressas a respeito. $E^{\prime}$ isso direito liquido e inconcusso" (1).

Dúvida jamais se esboçou a tal respeito, tanto em doutrina, quanto em jurisprudência. $\mathrm{O}$ dispositivo do código do comércio era claro demasiadamente para que ela pudesse formar-se.

4. O pagamento da cambial em moeda estrangeira Definindo a letra de câmbio e a nota promissória, o decr. 2.044, de 31 de dezembro de 1908, entre os requisitos daquela exigiu, em seu contexto, a menção, por extenso, da "sôma de dinheiro a pagar e espécie da moeda". Mas não ficou nisso. Enunciou, no art. 25, a regra de dever a letra de câmbio ser paga na moeda indicada. "Designada", esclareceu o texto, "designada moeda estrangeira, o pagamento, salvo determinação em contrário, expressa na letra, deve ser efetuado em moeda nacional, ao câmbio à vista do dia do vencimento e do lugar do pagamento".

Aduziu José A. Saraiva, em tôrno dêsse dispositivo, considerações dignas de nota. "Pela antiga doutrina", escreveu êle, "pela antiga doutrina, a sòma cambial devia ser

(1) Lafayette Rodrigues Pereira, Pareceres, vol. 1 (Direito civil), parecer n. 172, pag. 314. Rio de Janeiro, 1921. 
paga, no dia do vencimento do título, com a moeda indicada, ou, na falta de especificação; com a moeda em circulação na praça do pagamento. Tambem hoje, pelo art. 1, n. II, desta lei, a cambial deve indicar não só a sôma de dinheiro, como a espécie da moeda. Outras legislações e assim o substitutivo que foi apresentado à Câmara dos Deputados - limitam a exigência à declaração da sôma de dinheiro, sistêma pelo qual o devedor tem o direito de pagar com a moeda corrente na praça. A nossa lei, que reclama a determinação da espécie da moeda, elimina a faculdade de opção do devedor. Por ter o credor o direito de exigir a moeda indicada, claro é que o devedor somente ficará liberado pelo pagamento com a moeda referida; nórma esta harmônica com os princípios de direito comum, pelos quais o credor não está adstrito a receber coisa diversa da prometida, embóra de igual valor ou superior. Designada moeda corrente nas praças de emissão e do pagamento, com valor desigual, deve ser paga a importância correspondente ao do valor da moeda na praça do pagamento. Quando nâo expresso o curso do câmbio, o pagamento faz-se pelo câmbio à vista do dia do vencimento e praça do pagamento" (2).

5. A liberdade da convenção da moeda no regime do código civil - Sobrevindo, em 1916, o código civil, no ano seguinte' entrado em vigor, a regra dominante do pagamento manteve-se em pouco modificada. Erigiu êle, no art. 947, o principio cardial de fazer-se o pagamento em dinheiro, sem determinação da espécie, em moeda corrente no lugar do cumprimento da obrigação. Mas a espécie ficou, desde logo, circunscrita, na exceção àquela nórma primacial, consignada no primeiro parágrafo do artigo, nêstes termos: "é, porém, licito às partes estipular que se efetúe (o pagamento) em certa e determinada espécie de moeda, nacional, ou estrangeira". Não se admite, portanto, em face do dispositivo em exame, pagamento em dinheiro, que $375, \S 251$.

(2) Jost A. Saraiva, A Cambial, Rio de Janeiro, 1912, pag. 
se não exprima em moeda, "em certa e determinada espécie de moeda". Isso é substancial. Quem diz pagamento em dinheiro, afirma que tem êle de ser feito em moeda. A liberdade contratual, portanto, sofreu restrição insigne. Retirou-se aos contratantes a de pactuar o pagamento em outra espécie, que não fôsse a moeda. Podiam êles escolher entre a nacional e a estrangeira. Não em outra especie. E isso pela razão de ter o código estabelecido prescrição especial, em prol do devedor. Nêsse caso, no da estipulação do pagamento em moeda estrangeira, ficou expresso no segundo parágrafo, o devedor "póde, entretanto, optar entre o pagamento na espécie designada no título e o seu equivalente em moeda corrente no lugar da prestação, ao câmbio do dia do vencimento", prevalecendo o da véspera, ou seja a imediatamente anterior, em falta de cotação naquêle dia.

$O$ intuito do código foi o de permitir ao devedor liberar-se de sua obrigação, contraída em moeda estrangeira, mediante o pagamento da respectiva importância, calculada pelo câmbio do dia do vencimento, em moeda corrente brasileira. Incorrendo o devedor em móra e variando o ágio entre a data do vencimento e a do pagamento, atribuiu o texto legal ao credor optar por um dêles, se não estipulado câmbio fixo para a conversão. O oscilar de cotações da moeda estrangeira ajustada, no dia do pagamento, abre ensejo para a tomada por base do cômputo da moeda brasileira média do mercado naquêle dia.

6. A situação do devedor no desvalorizar-se da moeda pactuada - A desvalorização da moeda corrente, no entanto, criou, para os devedores, situações angustiosas, agravadas pela fixação prévia do câmbio de conversão da estrangeira na nacional. Aqui, como em outros países. A instabilidade monetária teve sua parte dramatica. De um lado, credores a exigirem cláusulas de garantia de câmbio, de molde a assegurarem-se do recebimento exato do equivalente da sua moeda forte; de outro, o progressivo empobrecimento dos devedores, com o montante de suas dividas 
acrescido, na proporção do desvalorizamento de sua moeda nacional.

7. O reajustamento econômico do devedor comerciante - Ao comerciante, surpreendido pelas injunções da politica monetária e pelas crises decorrentes da depreciação da moeda de seus pagamentos, era, e ainda é, permitido proceder ao próprio reajustamento econômico, pondo em equilíbrio o seu passivo com o seu ativo, mediante a redução daquêle, por via da propositura de concordata preventiva aos seus credores. Nem todos os comerciantes, entretanto, se serviram dêsse privilégio, aos de sua classes peculiar, pelas desvantagens dêle decorrentes, entre os quais sobressái a do seu descrédito pessoal. Para os civís, todavia, o problêma se apresentou em toda a intensidade, reclamando a atenção dos juristas.

Teve êle momento culminante, em 1929, data da grande crise, que assolou o país, ainda de todo não esmaecida. Perduram os seus efeitos.

8. A mutação dos valores e a órdem contratual Examinou-o, rapidamente, em páginas de revista, o autor deste trabalho, em dissertação elaborada naqueles dias penosos (3), em que abordou considerações a propósito de conceitos de FrançoIs GÉNY, apelando, naquela conjuntura, para os tribunais. Só êles poderiam preparar o terreno em que se assentaria a construção legislativa. Que podiam os juizes, inquiria o jurista francês, que podiam êles fazer, colocados deante de leis monetárias "de necessidade", de objetivo financeiro? Plenamente, doutrinou êle, "plenamente concientes de sua missão de justiça, hesitarão êles em deixar sem socôrro interêsses manif estamente legitimos, consagrando, por preguiçoso descuido, o desbaratamento de fortunas privadas e a ruina da organização social, que êles es-

(3) Waldemar Ferreira, a mutaçõo dos valores e a ordem contratual, na Revista Acadêmica da Faculdade de Direito do Recife, ano XXXVIII, 1930, pag. 91. 
tão encarregados de defender. Não podendo resignar-se a sancionar gritantes iniquidades, procurarão êles, por certo, entre os principios gerais do direito estabelecido, regras diretrizes, muitas vezes contidas nos textos, outras a êles superiores, que lhes permitam opôr barreiras às consequências brutais do valor nominal assinado e mantido, contra e para com todos, nos instrumentos monetários, a saber: regras de equidade geral, tais como a restituição do enriquecimento sem causa, lealdade e bôa fé na execução dos contratos, nulidade dos átos juridicos contrários aos bons costumes; regras de justiça positiva mais precisa, como a equivalência das prestações recíprocas nos contratos a titulo oneroso, na mantença necessária do conteúdo da obrigação primitivamente fixado, e a liberação do devedor pela impossibilidade, mesmo simplesmente econômica, da execução (Unerschwing lichkeit der Leistung). A utilização e a combinação engenhosa dessas regras, das quais cada uma comporta interpretação e, muitas vezes, discussão, podem ensejar a valorização judiciária dos compromissos pecuniários, seja, indiretamente, resolvendo os contratos não executados, seja, mais diretamente, modificando a taxa da obrigação primitivamente fixada, seja, ainda, ameaçando de resolução o contratante que não consentisse no aumento julgado razoavel. Essas soluções serão mais facilmente admitidas para as obrigações convencionais, cuja fonte nitidamente voluntária, abra jôgo livre ao espirito de justiça, das quais algumas, créditos hipotecários por exemplo, tenham apôio econômico mais firme. Elas se estenderão, naturalmente, por analogia, às responsabilidades jurídicas de órdem extracontratual e, finalmente, a todas as relações de órdem privada em que intervenha elemento medido em dinheiro (Geld)" (4).

Reconhecendo oferecer o problêma, de tanta relevância, qualificando valioso para despertar o debate, que reclama)

(4) JEAN Wasilkowski, Contribution à l'étude du problème de la valorisation dans le domaine du droit privé (Varsovia e Paris, 1929), prefácio, pag. VI. 
va, salientou o sinatário dêste trabalho a urgência de solução adequada, mas provinda da contribuição legislativa. Como poderiam os juizes, sem lei que lhes atribuisse poder para tanto, reduzir as prestações dos devedores, realizando o reajustamento dos valores de seu patrimônio?

9. As leis de emergência e o equilibrio contratual Se, como aconteceu em vários paises, a influência do curso forçado do papel moeda depreciado sôbre as relações de direito privado, deu resultados incompativeis com a equidade e com o sentimento do direito - o mesmo se verificou com a frequente estipulação dos pagaḿntos em ouro e em moeda estrangeira, em detrimento dos devedores. Leis de emergência procuraram restabelecer o equilibrio contratual. Assim nos outros países, assim no Brasil.

\section{CAPITULO II}

\section{A PRoIbiÇão E NULIdAde das AVênÇAS DE PAGA- MENTO EM OURO OU EM MOEDA ESTRANGEIRA}

10. A campanha nacionalizadora do pagamento dos serviços concedidos - $O$ sentido nacionalista, de que se impregnou o período ditatorial instituido em 1930, agora exacerbado mais que nunca, divisou nas estipulações de pagamento em ouro ou em moeda estrangeira anomalía carecedora de corrigênda. Instava, na voz de seus pregoeiros, modificar a política, que as tolerara, notadamente nos contratos de concessões de serviços públicos.

Quis o ministro da Viação daquela época por têrmo à anômala obrigação, em que brasileiros se achavam, mercê de leis e regulamentos, e de contratos celebrados pelo govêrno, de pagar, em ouro, serviços fornecidos ou concedidos pelo Estado. Nos de fornecimento de eletricidade, então, a força motriz era nacional. $O$ pessoal, empregado nas usinas e nos demais serviços técnicos e administrativos das em- 
prêsas concessionárias, recebia os seus vencimentos em papel. Ficavam estas, cobrando em ouro os seus fornecimentos, livres das oscilações cambiais que torturavam os consumidores. Para evitar essa situação díspar, o ministro da Viação representou ao chefe do govêrno provisório, solicitando as providências adequadas.

Porque se tratasse de assunto relacionado com o ministério da Fazenda, determinou aquêle examinasse-o êste, "com um critério amplo e tendo em vista a validade dos contratos ou convenções particulares que estipulam pagamento em ouro, ou utilizam outros artifícios para subtrair, dentro do território nacional, o credor privilegiado ao regime do papel moeda de curso forçado instituido por uma lei de órdem pública e exteriorização da própria soberanía do país".

Ouro, ou o seu equivalente, exigiam as companhias concessionárias de serviços públicos. Direitos em ouro reclamavam as repartições públicas. Quando não em ouro, em moeda estrangeira se pactuava o pagamento das compras in-

ternacionais.

11. A extinção do pagamento do mil réis ouro às repartições públicas - Dois decretos saíram da forja legislativa discricionária no dia 21 de novembro de 1933.

Mudando de orientação, o de n. 23.480, daquela data, extinguiu a recepção, nas repartições públicas, do mil réis ouro. Considerou-o, para todos os efeitos, "como se fosse mil réis papel de curso forçado". E isso por motivos de várias órdens. Estava suspenso, em vários paises, o funcionamento do padrão ouro. O mil réis era calculado na base do câmbio de Nova York sôbre o Rio de Janeiro, "câmbio apenas de curso comercial e não de diferênças entre as moedas ouro e papel". Decorriam, ademais, da situação cambial do mundo frequentes variações no valor em papel do mil réis ouro, moeda em que se arrecadavam os impostos aduaneiros e taxas correlatas. Modificavam essas oscilações automaticamente os efeitos das tarifas aduaneiras, 
agravando as perturbações que afligiam o comércio internacional. Ora, no prôemio do decreto se argumentava, a demasiada alta do ágio do ouro elevava grandemente aquelas tarifas, afetando, no mesmo sentido, os preços internos. Como não podiam, mercê do curso do dinheiro corrente, mesmo transitoriamente, coexistir duas moedas, ficou sustado, nas repartições públicas, o recebimento do mil réis ouro.

Questão assás debatida, ao seu tempo, foi a da arrecadação em ouro dos direitos de importação, sempre calculados em numerário, à taxa atual do câmbio, nunca efetivamente pagos em ouro, sem quebra, portanto, do curso forçado da moeda nacional. Adotando-a, intuito não animou ao govêrno senão o de equilibrar as flutuações cambiais. O imposto em ouro, na frase de RuY Barbosa, admitiu-se "como moderador da importação". Ele o disse em discurso pronunciado no Senado, em tópico merecedor de rememoração.

"A influência do imposto em ouro como moderador da importação é, com efeito, a primeira, talvez, das suas funções e o mais insigne dos seus benefícios. No balanço do comércio entre o país e o exterior ha deficits naturais, resultantes do movimento espontâneo das transações, da inferioridade dos valores nacionais consumidos nos mercados estrangeiros em relação aos valores estrangeiros absorvidos pelo mercado nacional. Mas a êsses acrescem os deficits voluntários, os deficits de ocasião, que a especulação comercial produz, e tem o maior interêsse em produzir, desde que os direitos de entrada se pagam em papel depreciavel, e o cavilador mercantil lucra, por aí, as diferenças na oscilação do câmbio entre a época, em que embólsa no país o valor das mercadorias importadas, e aquela em que as paga no interior.

"O processo da produção artificial desses deficits é simples. Basta que o especulador compre, nos mercados produtores, a longo prazo, elevando a importância das suas encomêndas além das exigências do consumo na quadra da operação. Dessas exagerações na importação resulta inevi- 
tavelmente a baixa do câmbio, proporcional ou excesso delas. E, como o valor dêsses suprimentos, no país, que os tem de absorver, ha de ser fixado segundo o câmbio, que a operação determinou, isto é, sob a influência da depreciação gerada por ela, a consequência é realizar o explorador as suas vendas, em moeda-papel, a elevados preços. Mas êsses deficits internacionais são, de sua natureza, transitórios. O equilibrio comercial tende, pois, a se restabelecer, ou, pelo menos, tende a minorar o desequilibrio no excesso correspondente aos manejos da especulação. O câmbio, em consequência, melhora. E o especulador, tão interessado agora na alta, quanto o era na baixa durante a primeira fáse do seu negócio, paga, no mercado estrangeiro, mediante cambiais adquiridas aqui a câmbio alto, isto é, a módico preço, os artigos que vendeu ao consumidor brasileiro a câmbio baixo, isto é, a preços avultados. As alternativas de alta e baixa no câmbio constituem, assim, copiosa fonte de renda para o especulador, que compra tanto mais barato, e vende tanto mais caro, quanto maior é a variação do câmbio, no período em que se desdobra a sua operaçã́o de compra e venda. Com essas variações, pois, nas quais o consumidor perde sempre, ganha as mais das vezes o especulador.

“Evidentemente, esta situação é uma anomalía intoleravel, a que urge pôr freio permanente e eficaz. Ora, o freio desejado está no pagamento em ouro dos direitos de importação; porque êsse encargo, interessando constantemente o importador na alta do câmbio, obriga-o a limitar as suas encomêndas confórme as necessidades do consumo. E' o que basta um dedo de senso comum, para compreender" (5).

Extinguindo a recepção dos impostos de importação em ouro, estabelecidos na defêsa da economia nacional, nos termos expostos e justificada por outros argumentos que agora não vêm ao caso, o govêrno provisório determinou, no entanto, pelo decr. n. 23.481, de 21 de novembro de 1933 ,

(5) Ruy Barbosa, Finanças e Politica da República. Discursos e escritos. Rio de Janeiro, 1892. Pag. 254. 
recebessem todas as repartições públicas arrecadadoras o antigo mil réis ouro, de valor variavel com as oscilações cambiais, na base de oito mil réis papel. $\mathrm{E}$ isso, na introdução daquele decreto ficou esclarecido, porque o curso forçado do mil réis e a inexistência do mil réis ouro trariam redução nas rendas alfandegárias e consulares. Mais, ainda, porque o equilíbrio orçamentário e a própria manutencão dos serviços públicos seriam prejudicados em vultosa redução de rendas. Cumpria, pois, ao poder público prover, no caso, afim de corrigir ou evitar êsses efeitos.

Não se deu, dessarte, a supressão dos direitos ou impostos de importação em ouro, senão a estabilização do mil réis ouro, em que êles continuaram a ser arrecadados, posto fóra das oscilações cambiais para o cômputo daqueles direitos. Passou êle a ter o valor fixo de oito mil réis papel.

12. A fixação da taxa de 15 shilings em moeda nacional - Prosseguindo na fâina nacionalizadora do mil réis, o govêrno provisório, pelo decr. n. 23.498, de 24 de novembro de 1933, mandou que a taxa de 15 shilings; arrecadada pelo Departamento Nacional do Café, nos termos do art. 1 do decr. n. 22.236, de 19 de dezembro de 1932, e decr. n. 22.542, de 10 de fevereiro de 1933, art. 4, fôsse cobrada na taxa fixa, em moeda nacional, de $45 \$ 000$. Deixou ela de ser calculada à paridade do dólar, ao câmbio fixado pelo Banco do Brasil para a venda de saques à vista sôbre Nova York. As frequentes oscilações cambiais do dólar perturbavam o andamento regular dos negócios do café e dificultavam a liquidação das obrigações em moeda estrangeira, que não o dólar.

13. A decretação da nulidade do ajuste de pagamento em moeda estrangeira - De reflexo muito maior foi o decr. n. 23.501, de 27 de novembro de 1933. Consignou nêle o ministro da Fazenda, dando cumprimento ao determinado pelo chefe do govêrno provisório, substitutivo ao projeto do ministro da Viação, "eliminando os pagamentos em ouro por 
serviços industriais prestados no país". Foi êste o objetivo a principio colimado. O substitutivo, afinal convertido em lei, teve maior amplitude, como o deixou manifesto o ministro da Fazenda, na longa justificação, que alcançou a mais viva controvérsia, naquêle tempo. Desarrazoado não é, por isso, reproduzíla agora. Não se cuida, nesta órdem de considerações, senão examinar os intuitos da politica diretora da nacionalização do mil réis.

Está assim a justificação concebida:

“1. E' principio inconteste a força de lei aos contratos legalmente concluidos para as partes contratantes.

"A guerra mundial, porém, veiu, com sua série de desequilibrios econômicos e financeiros, criar, por circunstâncias imprevisiveis extracontratuais, uma excessiva onerosidade, falseando brutalmente a economia do contrato. A lei FAILlot admitiu a suspensão e, até, a resolução dos contratos concluidos antes da guerra. Apesar das reservas com que foi recebida pela jurisprudência francesa de então posteriormente, quando surgiu a lei de 6 de julho de 1925, autorizando a revisão dos contratos de locação - ninguem mais discutiu sua integral aplicação.

"2. Qual o fundamento dessas medidas extremas? Eis o que ensina RIPERT:

"A revisão dos contratos é permitida, desde que se verifique um acontecimento extraordinário, fóra da previsão humana, tornando a execução tão onerosa que venha a constituir uma lesão desproporcional com as vantagens previstas ao se firmar o contrato".

“3. Foi o que se verificou, entre nós, com o decreto $n$. 19.573, de 7 de janeiro de 1931, permitindo a resolução ou modificação das locações de prédios, feitas por funcionários públicos demitidos, removidos, ou cujos vencimentos houvessem sido reduzidos em mais de $25 \%$. Este decreto mereceu os aplausos de Clovis Bevilaqua. Vêde Direito das Obrigações, 3. ${ }^{a}$ edição. Rio, 1931, p. 346/7.

"4. Posteriormente: decreto n. 19.473, de 10 de dezembro de 1930 , retificado pelo de n. 19.754 , de 18 de março de 
1931, regulando os conhecimentos de transportes de mercadorias (art. 11, $\S$ único, e o decreto n. 22.626, de 9 de abril de 1933 (regulando a usura), extremamente retroativos, são paradígmas desses princípios.

" 5 . O que se deve procurar nos contratos é a comum intenção das partes; cessa essa obrigação quando a primitiva situação econômica sofrer uma imprevista e profunda modificação (cfr. Albert WAHL, in Revue Trimestrielle de Droit Civil, 1918, p. 65).

“6. Surge, então, a função do govêrno político ordenando os ajustamentos por classe de negócios, tendo em vista as relações de meio e tempo, ante a superveniência imprevista e imprevisivel constitutiva para o credor duma fonte de enriquecimento inesperado (cfr. Arnoldo Medeiros, Caso fortuito e teoria da imprevisão, Rio, 1932, pag. 195; ArThur Rocha, Da intervenção do Estado nos contratos concluidłos, Rio, 1932, p. 149).

“7. $\mathrm{O}$ ato aqui expedido tem integral aplicação quanto à cláusula ouro, convencionada como moeda única do contrato, mesmo quando estipulada como garantia de câmbio, permitindo a liberação em papel moeda pelo valor correspondente à metalica na ocasião do pagamento.

a) "Le cours forcé écarte toute convention contraire, qu'il lui est supérieure et qu'il la domine, parce que d'ordre public. La clause de paiement en or est paralisée tant que dure le cours forcé". Eugène SchKaff, La depréciation monetaire, ses effets en droit privé, Paris, 1925, p. 168.

b) "Les lois nouvelles qui changent la valeur intrinséque de la monnaie ont un effet immediat sur les contrats en cours... On a dit alors que les lois nouvelles qui modifient le régime monétaire devaient s'appliquer aux contrats en cours comme lois d'ordre public contractuel. Mais cela n'est point suffisant pour définir les effets de la loi nouvelle, car on pourrait croire que la loi nouvelle a effet seulement vis-à-vis des débiteurs contractuels. Or c'est lá une erreur evidente: la loi nouvelle a effet vis-à-vis de tous les 
débiteurs, que leur dette vienne d'un contrat ou qu'elle vienne d'une outre source. Et précisement, si elle a effet dans les contrats en cours, c'est parce qu'elle n'est pas une loi relative à une situation contractuelle, mais une loi relative $\dot{a}$ un estatut légal, le estatut de la monnaie; la loi, considerée comme loi de droit public, atteint tous les sujets de l'Etat, elle les atteint aussi bien dans les contrats qu'en dehors de tout contrat; c'est une erreur de considerér que la loi est relative aux contrats". (PAUL RouBiER, Les conflits de loi dans le temps, Paris, 1933, vol. 2, p. 136, 127).

c) "Les lois qui ont établi le cours forcé du billet de banque ont fait de celui-ci une monnaie fiduciaire obligatoire, ayant la même valeur liberatoire que la monnaie métallique" (CAPITANT).

d) "Sous le régime antérieur, elle est nulle, car elle porte atteinte à l'órdre public, par l'obstacle qu'elle oppose à la libre circulation des billets; elle contrevient directement aux lois qui, dans un interet supérieur, ont édicté le cours forcé. Ces lois constituent des veritables lois de police et de sûreté, d'une portée territoriale et s'imposent à tous (art. 3 al, 1, Civ.); elles sont même assorties d'une sanction pénale par l'art. 475, § 11 Pén., qui punit des peines de simples police le fait de refuser en paiement une monnaie ayant cours légal. - Paris, 22 févr. 1924, Dumas c/ Grenouileaus (Clunet, 1924, p. 691) et les conclusions de M. Dreyfus (Gaz. Pal. 1924, 1. 364; Coemar, 20 nov. 1921 (Rev. jur. Als. Lorr. 1922, p. 97); Coemar, 13 mai 1924 (Ibid., 1924, p. 284, note (Wilhelm). AdDE Wilhelm, Stipulation en monnaie depreciée (Ibid., 1924, p. et 145 et s.)".

"De fait, la doctrine s'accorde avec la jurisprudence relatée ci-dessous pour annuler la clause d'or sous l'aspect qui vient d'être indiqué. GÉNY, La validité juridique de la clause payable en or (Rev. trim. de droit civil, 1925, p. 5 et 1); Niboyet, Des conflits de lois relatifs aux paiements depuis la derniére guerre (notre Revue, 1925, p. 161); VALÉRY, La clause payable on or et le cours forcé (CLUNET, 1916, p. 1.132)". (LAPRADELlE et NiBOYET, Repertoire de droit 
international, vol. 3, vb. change, cours forcé monnaie de paiment, valorisation, ns. 30 et 32 , p. 240)".

Sob o influxo de princípios e considerações de tal monta se elaborou o decr. n. 23.501, de 27 de novembro de 1933. Concretizou-se êle em tres disposições muito simples, a saber:

“Art. 1. E' nula qualquer estipulação de pagamento em ouro, ou em determinada espécie de moeda, ou por qualquer outro meio tendente a recusar ou restringir, nos seus efeitos, o curso forçado do mil réis papel.

“Art. 2. A partir da publicação dêste decreto, é vedada, sob pena de nulidade, nos contratos exequiveis no Brasil, a estipulação de pagamento em moeda que não seja a corrente, pelo seu valor legal.

“Art. 3. O presente decreto entrará em vigor na data de sua publicação, devendo seu texto ser transmitido aos interventores para publicação imediata, revogadas as disposições em contrário, incluidas as de caráter constitucional".

14. A justificação governamental da medida - Não bastou a justificação do ministro da Fazenda. Longa introdução antecedeu o decreto; e o chefe do govêrno o expediu,

"considerando que é função essencial e privativa do Estado criar e defender sua moeda, assegurando-lhe o poder liberatório;

"considerando que é atribuição inerente à soberanía do Estado decretar o curso forçado, como providência de ordem pública;

"considerando que, uma vez conferido ao papel moeda o curso forçado, não póde a lei, que o decretou, ser derrogada por convenções particulares, tendentes a ilidir-lhe os efeitos, estipulando meios de pagamento que redundem no rępúdio ou na depreciação desta moeda, a que o Estado afiançou poder liberatório igual à moeda metálica;

"considerando que o $\S 1$ do art. 947 do código civil, como disposição geral destinada à perpetuidade, não colide 
com a existência, por sua natureza transitória, do curso forçado, mas enquanto perdura não póde aquêle ser aplicado;

"considerando que em quase todas as nações tem sido decretada a nulidade da cláusula ouro e de outros processos artificiosos de pagamento, que importem na repulsa ao. meio circulante;

“considerando que, além dos países cujos sistemas monetários sofreram profundo abálo, pela desvalorização quase total de sua moeda fiduciária, a França, a Inglaterra e os Estados Unidos adotaram rigorosas medidas, entre as quais muitas das abaixo prescritas, para evitar, ou sustar a depreciação de sua moeda papel;

"considerando que em França, mesmo antes da lei de 25 de junho de 1928, a jurisprudência, desde 1873, se firmara pela nulidade da cláusula ouro, por contrária à órdem pública, no regíme do curso forçado, exceto para os pagamentos internacionais, como se deduz e verifica dos arestos da Côrte de Cassação de 11 de fevereiro de 1873, 7 dejunho de 1920, 9 de março de 1925, 15 de abril de 1926, 17 de maio de 1927 e 13 de junho de 1928;

"considerando que tambem se manifesta contrária à cláusula ouro a jurisprudência inglêsa, cuja aresto mais recente é da Court of Appeal de Londres, que, em abril do ano corrente, mantendo a sentença da High Court of Justice, no caso Feist v. The Company, decidiu que a Société Belge d'Eléctricité poderia pagar "em qualquer moeda" as suas obrigações de 100 libras, declaradas nos títulos "libras peças de ouro esterlino da Inglaterra, iguais ou equivalentes em peso de ouro fino às de 1 de setembro de 1928";

"considerando que os Estados Unidos, pela Joint Resolution, sancionada a 6 de junho último, declararam nula qualquer cláusula que faculte "ao credor o direito de exigir o pagamento em ouro ou determinada espécie de moeda ou em sôma equivalente de dinheiro dos Estados Unidos, calculada sôbre tal base", e determinaram que "qualquer obrigação anteriormente contraída, embóra nela se contenha semelhante disposição, será resgatada pelo pagamento dólar 
por dólar, em qualquer moeda metálica ou papel de curso legal";

"considerando que providências dessa natureza, tomadas pelo Estado no exercício de suas funções soberanas e por altas razões de órdem pública, não podem deixar de abranger nos seus efeitos as convenções anteriores à publicação da lei;

"considerando que é geral a retroatividade de tais medidas, como se verifica da Joint Resolution citada; do decreto alemão de 28 de setembro de 1914, quando prescreve que "as convenções celebradas antes de 31 de julho de 1914 e pelas quais o pagamento devia ser feito em ouro, cessam até nova órdem de obrigar as partes"; do decreto belga de 2 de agosto de 1914; da lei rumêna de 21 de dezembro de 1916; da lei grega de 21 de julho de 1914; da lei búlgara de 12 de maio de 1921, e do decreto francês de 18 de setembro de 1790, que assim dispunha: "todas as somas por estipulações pagaveis em espécie poderão ser pagas em assinados ou promessas de assinados, não obstante todas as cláusulas ou disposições em contrário;

"considerando, portanto, que não póde ter validade legal no território brasileiro qualquer cláusula, convenção ou artifício, que vise subtrair o credor ao regíme do papel moeda de curso forçado, recusando-lhe ou diminuindo-lhe o poder liberatório integral, que o Estado em sua soberania lhe conferiu;

"considerando que o contrário seria admitir a possibilidade de convenções de direito privado derrogarem leis de direito público".

15. A repercussão do diploma legislativo no mundo dos negócios - Fundamente repercutiu, como não podia deixar de ter acontecido, o decr. $n$. 23.501, de 27 de novembro de 1933, no mundo dos negócios e no do direito. Pareceu, desde logo, a quantos ficaram aturdidos pelos argumentos introdutórios do decreto, que se imprimia, com êle, curso forçado ao mil réis brasileiro, destituido, por isso, de força de circulação e de poder liberatório. Julgou-se incompativel 
com tais qualidades a estipulação de pagamento em moeda estrangeira ou em ouro. Acentuou-se, por outro lado, a transitoriedade do curso forçado do papel moeda, e a perpetuidade da disposição do código, que tornara livre às partes a estipulação do pagamento em certa e determinada espécie de moeda, nacional, ou estrangeira, quando o contrário, precisamente, se verificava. Moeda sem curso forçado e sem poder liberatório não passa de titulo puro e simples de crédito contra o Estado emissor. Moeda é que não é. Muito menos moeda corrente. Destina-se a moeda a funcionar, precipuamente, como meio de pagamento das obrigações pecuniárias. Seja mercadoria, como querem alguns; seja bem econômico, como outros a qualificam; ou medida e representação de valor, equiparada a titulo de crédito emitido pelo Estado - a moeda-papel inconversivel, como a brasileira, só desempenha a sua função econômica e jurídica, se dotada de curso forçado ou legal, que a torna irrecusavel, operando a remição das dividas contraídas e expressas em dinheiro.

Não é de agora, como bem se compreende, o curso forçado do mil réis papel.

16. A introdução no meio circulante do papel fiduciário de curso forçarlo - Criado, pelo alvará de 12 de outubro de 1808, o Banco do Brasil, atribuiu-lhe êle faculdade de emitir letras ou bilhetes pagaveis ao portador e à vista ou a certo praso de tempo. Embóra sem curso expressamente obrigatório, os bilhetes por êle emitidos, mercê de formal declaração de seus estatutos de que seriam pagaveis em a moeda circulante (metais), a vista ou o prazo, passaram a ser instrumentos de trocas (6). Introduziu-se, dessarte, no meio circulante nacional, o papel fiduciário e bancário, de curso forçado, conversivel, no entanto, em moeda metálica, ao portador e a vista. Circulou êle como moeda corrente, até que as vicissitudes, por que passou o Banco do Brasil,

(6) Antonio Carlos Ribeiro DE Andrada, Bancos de Emissão rio Brasil (Rio de Janeiro, 1923, ed. da Livraria Leite Ribeiro), pag. 15. 
agravadas pelas retiradas feitas pela côrte portuguêsa regressante para a Europa, que o deixaram exausto, o levaram à extinção. Foi isso em 11 de dezembro de 1829. Pôsto ele em liquidação, as notas, por êle emitidas e em circulação, foram substituidas por notas de novo padrão, circulando elas, no entanto, como moeda corrente, e de curso forçado, até completo resgate.

Começou, então, a correr, sem solução de continuidade, a moeda papel, que ainda hoje é a moeda corrente, que não poderia produzir os efeitos, que dela advieram, se destituida do curso forçado, que então se lhe imprimiu e jamais perdeu. Não se diminuiu sua correnteza com a liberdade, que sempre tiveram as partes, de ajustar o pagamento de suas obrigações em moeda estrangeira, principalmente nas compras internacionais, diante da faculdade, que a lei reservou aos devedores, de efetuar, em juizo, o pagamento ou a consignação, do equivalente, calculado pelo câmbio do dia do pagamento ou dia anterior mais proximo, quando naquêle não cotado. O dispositivo do art. $947, \S 1$, do código civil, nunca serviu de embaraço ao curso fluente do mil réis papel, em razão do poder liberatório dêste e da conversibilidade da moeda estrangeira na nacional, pela fórma e pelo câmbio previstos em lei.

17. A nulidade de estipulação de moeda estrangeira nos contratos exequiveis no Brasil - Deixando de lado considerações a êsse respeito, o certo é ter o decr. n. 23.501, de 27 de novembro de 1933, ferido de nulidade as estipulações de pagamento em ouro, ou em determinada espécie de moeda ou por qualquer outro meio tendente a recusar ou restringir, nos seus efeitos, o curso forçado do mil réis papel. Vedou êle, sob a mesma pena, estipulação, nos contratos exequiveis no Brasil, de pagamento em moeda que não a corrente, pelo seu valor legal.

18. A irretroatividade dos direitos e os contratos de serviço público e particulares - Contradição, entre os dois enunciados divisada, cuidou Carlos Maximiliano de desfa- 
zer. Foi em parecer, de 27 de dezembro de 1933, que correu impresso. Recorrendo ao elemento histórico do decr. n. 23.501 , de 27 de novembro de 1933 , nele mesmo resumido e páginas atrás reproduzido, inferiu êle referir-se o artigo primeiro às concessões de serviços públicos e o artigo segundo aos contratos e convenções particulares. " $O$ artigo primeiro", doutrinou, "o artigo primeiro, assim entendido, encontra outro apoio - o art. 7 da Lei Orgânica (decr. n. 19.398, de 11 de novembro de 1930), que autoriza os poderes nacionais a expungir das concessões o que se não coaduna com o interêsse público. Tanto não houve o intuito de impôr a retroatividade $a$ outrance, que aos próprios concescionários a mesma autoridade não impôs cobrar em papel exatamente a mesma quantidade do mil réis ouro; mandou entrar em acôrdo, tendo em vista o encarecimento da vida. O espírito do texto positivo assim se nos antolha: desde já, ficam os concessionários de serviços públicos impedidos de apresentar ao povo contas de pagamento em ouro (salvo abrandamento de rigor da nórma feita pelo govêrno por espírito de equidade); para o futuro, nem os particulares poderão convencionar o pagamento em moeda diferente da que tem, por lei, curso forçado no país".

A distinção, por tal fórma feita, no entanto, era puramente arbitrária. Não existia, no art. 1, alusão nenhuma a concessões de serviços públicos, de fórma a só a elas alcançar. Não contém tão pouco o art. 2 restrição, a abranger apenas os contratos particulares. Ha, nos dois textos, excessiva generalidade. Focalizaram quaisquer estipulações de pagamento em ouro ou em determinada espécie de moeda, com o propósito evidente de ferir de nulidade as preteritas e de impedir as vindouras. Interpretando-os, a Quinta Câmara da Côrte de Apelação de São Paulo chegou, no acórdão de 4 de setembro de 1935, a esta conclusão: "o art. 1 refere-se às cláusulas de pagamento em ouro existentes nos contratos já celebrados na data do decreto: aí está sua 
retroatividade. 0 art. 2 refere-se aos contratos futuros: aí está a proibição" (7).

19. A contenda a proposito da retroatividade do decreto - Que pudesse o decreto proibir a inserção, nos cóntratos, de futuras convenções de pagamento em ouro ou em moeda estrangeira, não se contestou. A contênda se travou quanto a sua retroatividade. As avênças anteriores, argumentavase, celebradas sob a égide de dispositivos legais expressos, não podiam ser invalidadas por átos do govêrno provisório. Carecia êle, acrescentava-se, de poder para aniquilar o direito adquirido em consonância com a legislação anterior. Logrou vivacidade o debate, na doutrina e no pretório. Mas, afinal, apurou-se não ter o texto atingido seu objetivo integralmente.

20. A subsistência das obrigações e a nulidade de estipulação de moeda - Fulminando de nulidade as estipulações de pagamento em ouro ou em moeda estrangeira, o decreto n. 23.501, de 27 de novembro de 1933, entretanto, não declarou nulas as obrigações. Nem as dividas pagaveis em ouro ou moeda estrangeira. Subsistiu o direito creditório. Permaneceu a obrigação de pagar. Melhor fôra, realmente, houvesse o decreto operado a conversão compulsória da moeda estrangeira na nacional, estabelecendo a taxa da operação. Disso resultou continuarem os devedores na obrigação de pagar e afligidos, desde aquele momento, com a incerteza do montante de sua divida.

De caso interessante conheceu a Segunda Câmara da Corte de Apelação de São Paulo, de que dá notícia o acórdão de 27 de novembro de 1936, nestes termos:

"Trata-se de um mútuo com garantia hipotecária, feito em francos. Nas escrituras fixaram-se, respectivamente, em quatrocentos réis e trezentos e oitenta e sete réis as taxas pelas quais as quantias mútuadas seriam entregues, em moe-

(7) Revista dos Tribunais, de São Paulo, vol. 98, de 1935, pag. 439; Arquivo Judiciário, do Rio de Janeiro, vol. 36, de 1936, pag. 214. 
da nacional, aos agravantes. Pretendem êles agora que a restituição do capital seja feita à mesma taxa pela qual receberam a quantia mutuada. A isso, porém, se opõem os contratos, que determinam seja o pagamento ou restituição em moeda francêsa ou no seu equivalente em moeda nacional, ao câmbio oficial da véspera. Para possibilitar a expedição do mandado e o pagamento incontinenti, fez-se a conta na inicial, tomando por base a taxa de quinhentos e quarenta réis, que era a do dia anterior. Acham os agravantes que isso não está certo. Não se devia respeitar o contrato, mas a lei; e esta manda que a conta seja feita tendo-se em vista o câmbio do dia do contrato. Assim raciocinam os agravantes, mas sem razão.

“ $O$ decr. n. 23.501 , de 27 de novembro de 1933, é completamente omisso quanto à taxa de restituição. Não diz qual seja: se a mesma pela qual se entregou, em moeda nacional, o seu equivalente em ouro; se a vigorante na data do contrato; se a prevista no contrato ou a prescrita no código civil. Ante êsse estranho silêncio do legislador é profundamente arbitrário adotar-se o câmbio da conversão inicial. Tal solução atenderia aos interêsses do devedor, que restitúe na mesma base em que recebeu. Esquece-se, porém, a situação do credor, que não poderá, com essa quantia, em moeda nacional, obter o equivalente em moeda estrangeira.

"Ante a lacuna da lei, tem-se opinado pela aplicação do código civil, cujo art. $947, \S 2$, adota o câmbio do dia do vencimento. Esta solução, defendida pelo Dr. Esperidião de Carvaluo, Revista de Direito, v. 112, pag. 50, é tanto mais de se aceitar quanto o legislador, nas considerações preambulares do decreto, só declarou suspenso o art. 947, §1. Ao $\S 2$ não se referiu, porque não foi objeto de suas cogitações a taxa de restituição.

"Na espécie, entretanto, impõe-se a aplicação da taxa da véspera do dia do pagamento, porque foi isso o que convencionaram as partes. Sendo os contratos anteriores ao decr. n. 23.501, não é possivel aplicar-se-lhes, retroativamente, êste decreto. O que vale é a lei e não os conside- 
randos que a justificam. Se nêstes o legislador tornou clara a intenção de regular tambem os contratos anteriores, naquela nada disse a respeito. Ora, não ha retroatividades tácitas ou por inferência. A doutrina, sustentada pelo acórdão que se lê na Revista dos Tribunais, vol. 96, pag. 143; pelo parecer do professor Azevedo Marques, publicado na mesma Revista, vol. 95, pag. 49; e por uma das Câmaras da Côrte de Apelação do Rio de Janeiro (informação constante do voto do sr. Costa Manso, Revista Forense, vol. 66, pag. 491) é, sem dúvida, a melhor" (8).

21. A fixação do montante das dívidas em moeda estrangeira - Posta de lado, no momento, a questão da retroatividade, consignou o acórdão ponto de relevância: o de, declarada a nulidade das estipulações de pagamento em ouro ou moeda estrangeira, não ter o decreto estabelecido critério para a fixação, em moeda corrente, do valor da divida por êle não atingida. Nada mais era prevalecesse a regra preexistente de computar-se aquêle valor pelo câmbio do dia do vencimento ou, em falta de cotação nêsse dia, pela imediatamente anterior.

O critério, adotado pelo acôrdão transcrito, foi seguido, não obstante, por vários átos legislativos e regulamentários.

22. O cômputo da moeda estrangeira e o imposto do sêlo - Dando regulamento à lei n. 202, de 2 de março de 1936 , que dispôs sôbre o sêlo federal, o decreto n. 1.137, de 7 de outubro de 1936, não se esqueceu de dar regra para o cálculo do sêlo dos documentos em que se estipulasse o pagamento em moeda estrangeira. Nêsses documentos, prescreveu êle, no art. 18, "nos documentos em que fôr estipulado o pagamento em moeda estrangeira, o cálculo para cobrança do sêlo será feito pela taxa contratada, e, na sua falta, pelo câmbio da véspera da data do contrato; não havendo êste, pelo câmbio da véspera da data do pagamento da obri-

(8) Arquivo Judiciário, do Rio de Janeiro, vol. 42, de 1937, pag. 120. 
gação". Não se tem à vista méra tolerância, mas a admissibilidade do pacto de pagamento em moeda estrangeira, inevitavel, de resto, nas compras internacionais. Não mudou de orientação, todavía, o decreto-lei n. 4.655 , de 3 de setembro de 1942. "Nos papéis", dispôs êle, no art. 43, "nos papéis em que o valor estiver expresso em moeda estrangeira, o imposto será pago pela equivalência em mil réis, ao câmbio do dia anterior, se, nesses papéis, não houve taxa estipulada". Pelo contrário, admitiu ele a possibilidade de conservar-se a taxa de convenção.

Proibindo a abertura de contas correntes, em moedas estrangeiras, aos bancos e casas bancárias estabelecidas no país, o decr. n. 21.316, de 25 de abril de 1932, havia determinado a liquidação imediata das existentes, pelo equivalente em moeda nacional, ao câmbio da data da publicação daquêle decreto.

Posteriormente, o decr. n. 5.493, de 9 de abril de 1940, que deu novo regulamento ao Instituto de Aposentadoria e Pensões dos Comerciários, não se mostrou intolerante para com a cláusula de pagamento em moeda estrangeira. "Os vencimentos", dispôs êle no art. 79, "os vencimentos percebidos em moeda estrangeira serão, para os efeitos das contribuições estabelecidas neste regulamento, convertidos em moeda nacional pelo câmbio que vigorar no primeiro dia útil de cada mês".

Desapareceu a quisilia contra a estipulação de pagamento em moeda estrangeira, incapaz, de resto, de impedir o curso forçado do mil réis, única moeda liberadora admitida no país e nêle corrente. Ou se caminharia para politica sadía de estabilização cambial; ou se determinaria a taxa de conversão compulsória da moeda estrangeira na brasileira.

Esta é a prática seguida por várias leis e regulamentos, posteriores ao decr. n. 23.501, de 27 de novembro de 1933.

23. As dívidas em moeda estrangeira e o reajustamento econômico - Concedido o reajustamento econômico, pela 
redução a cincoenta por cento do valor, em 1 dezembro de 1933, de todos os débitos de agricultores, contraídos antes de 30 de junho daquêle ano, adjetivados com garantia real, expresso ficou no art. 20, a), do decr. n. 24.233, de 12 de maio de 1934, em que se consolidaram os dispositivos legislativos e regulamentários do instituto, não se incluirem no seu regime as dividas contraidas em moeda estrangeira, salvo quando ajustadas dentro do país e nêle exigiveis, devendo o valor destas ser calculado pelo câmbio da data do contrato. Sofreu, com esse preceito, profundo golpe o decr. $n$. 23.501, de 27 novembro de 1933. As estipulações de pagamento em moeda estrangeira ou em ouro adquiriram explicitamente vitalidade, fixado, porém, o câmbio por que se operaria a conversão da moeda estrangeira na nacional: o da data do contrato.

24. A convenção de moeda em contrato com garantia hipotecária - Sob novo aspecto encarou o problema o decreto-lei n. 1.079, de 27 de janeiro de 1939. "Os contratos", preceito é do seu art. 1, "os contratos de empréstimo de dinheiro, celebrados no território nacional, até 1 de dezembro de 1933, com garantia de hipoteca de bens imóveis situados no Brasil, embóra o valor da quantia mutuada haja sido expresso em ouro, ou em moeda estrangeira, reputamse convencionados em moeda papel nacional, desde què nesta moeda tenha sido fornecida a importância ao mutuário". Objetivou o decreto-lei a situação de fato. Desde que a importância do empréstimo, em dinheiro, foi fornecida ao mutuario em moeda papel nacional, a divida se reputa constituida nessa moeda, a despeito de expressa em moeda estrangeira ou em ouro. Quem deu emprestado dinheiro brasileiro de dinheiro brasileiro é credor. Não de moeda estrangeira. Nem de ouro. Nèste caso, advertiu o decretolei, em parágrafo único, "nêste caso, o mutuário só é obrigado a restituir ao mutuante, nos termos e condições do contrato, a quantia em moeda papel nacional que houver recebido, ao ser realizado o pacto". 
Não ha, em tal caso, falar em conversão de moeda estrangeira em nacional. Nada disso. Para pagar em moeda brasileira, não tem o mutuário mais a fazer do que a prova de ter recebido a importância dada em empréstimo em moeda corrente. Só isso. Reduziu-se a questão a prova. de fáto.

25. A inaplicabilidade do decreto aos contratos liquidados e amortizações - Dando novo rumo ao problêma, o dècreto-lei não se absteve de enfrentar os casos ocorridos. Consagrou, no seu art. 2, sua inaplicabilidade "aos contratos já liquidados, nem às amortizações já efetuadas do capital mutuado, mesmo que o tenham sido na moeda expressa no contrato. Aplica-se, porém, aos contratos vencidos e não liquidados e à parte não resgatada do capital mutuado, bem como às execuções pendentes, resultantes desses contratos, ainda que a penhora tenha sido julgada por sentença, de que já não caiba recurso".

A amortização parcial da sôma emprestada submete o saldo em debito à conversão em moeda nacional, à taxa cambial do dia em que o contrato se celebrou.

26. A derrogação do preceito por disposição contratual - Pensou-se na possibilidade de os interessados, por cláusula expressa, afastarem a possibilidade da conversão da moeda estrangeira na nacional. Tal pensamento, porém, a despeito de concretizado algumas vezes, desvaneceu-se, diante da força do preceito de órdem pública, que as partes não podiam, absolutamente, dispensar. Não foi tanto no interêsse delas, quanto, e principalmente, no público, que a conversão se decretou. Decretou-se e ficou a independer da vontade delas, como resultante de circuustâncias de fato. Ela se operaria, realmente, nos contratos de empréstimos de dinheiro: a) celebrados no território nacional até 1 de dezembro de 1933; b) garantidos com hipoteca de bens imóveis situados no Brasil; c) desde que a importância mu- 
tuada tivesse sido fornecida em moeda papel nacional, embóra expressa em ouro ou em moeda estrangeira.

Onde, portanto, confluissem esses tres requisitos, assim desdobrados do texto legal, a expressão de moeda de pagamento diversa da nacional, ou em ouro, se teria como feita em moeda corrente brasileira, na quantia efetivamente dada por empréstimo ou, se já amortizada, no tanto quanto ainda restasse por pagar, operada a conversão pela taxa cambial da data do contrato.

Eram os empréstimos, realmente, e na generalidade dos casos, simuladamente feitos em moeda estrangeira. Bancos estrangeiros, de ha muito aqui instalados e operando exclusivamente com dinheiro nacional, recolhido de seus correntistas, com este movimentavam suas carteiras de empréstimos a prazo longo e com garantia hipotecária, mas faziam constar das escrituras respetivas terem ministrado a quantia mutuada em moeda estrangeira. Evidente era a simulação. Até bancos nacionais, e, entre eles, bancos oficiais, assim agiam. Veiu, pois, o decr. n. 1.079, de 27 de janeiro de 1939, reduzir todos os empréstimos dessa natureza e nas condições estabelecidas, ao mesmo denominador comum. Quem recebeu, efetivamente, moeda estrangeira, nessa devia efetuar o pagamento. Quem, porém, embolsou moeda corrente brasileira, em outra não era mais obrigado a realizá-lo.

Teve o diploma proposito indisfarçavel e declarado: o de operar, compulsoriamente, a conversão da moeda estrangeira na nacional, nos emprestimos garantidos com hipotéca de imóveis situados no país, "desde que nesta moeda tenha sido fornecida a importância ao mutuário". Eis o primacial requisito. O empréstimo devia ter sido efetuado em moeda nacional e ser pagavel em moeda estrangeira. Embôlso em moeda nacional. Reembôlso em moeda estrangeira. Nesse caso, a conversão seria, até, impropriedade terminológica. Porque a lei nem cogitou da taxa cambial da conversão. Mais precisamente, obrigou o mutuário “ $a$ restituir ao mutuante, nas condições e termos do contrato, 
a quantia em moeda nacional que houver recebido, ao ser realizado o pacto".

De restituição, portanto, e só disso, cuidou à lei. Restituir é repôr. Só repõe quem devolve, exatamente, o que retirou, ou recebeu.

\section{CAPITULO III}

\section{O DEPósito dos PAgamentos de TITUlos DA IMPORTAÇÃO DE MERCADORIAS}

27. O depósito do montante dos titulos em moeda estrangeira - Excluidos, como ficaram, do regíme de defêsa da moeda nacional os pagamentos internacionais, exigiu, no entanto, o decr. n. 24.038, de 26 de março de 1934, nos vencimentos dos títulos a prazo ou a vista, em moeda estrangeira, sacados sobre qualquer praça do país, o deposito de seu equivalente em moeda nacional ao câmbio do dia, feito no banco portador dos mesmos. Era a instituição de nova fórma de pagamento. Realizar-se-ia este pelo deposito, em tais termos. Tanto assim era que a falta deste equivalia à de pagamento, para efeito do protesto dos títulos.

As importâncias recebidas em deposito creditavam-se em nome do sacador ou endossador do título, afim de converterem-se em moeda estrangeira, logo que possivel a respectiva cobertura. Reservou-se ao banco depositário o direito de somente operar a conversão depois de comprovada a importação das respectivas mercadorias e de paga a diferença de câmbio, pois corria por conta dos sacados as diferênças verificadas entre as taxas do deposito e do fechamento do câmbio.

Conferiu a lei, ademais, ao portador do titulo, e para a cobrança da diferença de taxa, a ação e direitos inerentes à cambial, sendo, porém, para seu exercício, necessário o protesto. 
28. As obrigações oriúndas dos paises sob contrôlo estrangeiro - Diante da situação criada pelo conflito europeu, no qual varios países foram invadidos e seus govêmos exilados substituidos pelos dos invasores, o decreto-lei n. 2.703, de 28 de outubro de 1940, tornou obrigatório o depósito em moeda nacional, de que trata o decr. n. 24.038, de 26 de março de 1934, do equivalente às obrigações em moeda estrangeira, originárias de países cujas operações comerciais e bancárias com o exterior pudessem estar sujeitas ao contrôlo de govêrno estrangeiro. Ao mesmo regime sujeitaram-se as obrigações originárias das possessões de tais países, fôsse qual fôsse em relação ao conflito.

De outro lado, os títulos, representativos das obrigações atingidas pelo decreto-lei, não podiam ser entregues ao devedor, nem ao representante do credor, nem devolvidos ao remetente do exterior, sem a prévia autorização da Fiscalização Bancária do Banco do Brasil. As firmas, que possuissem documentos de importação de mercadorias originárias daqueles países, e de suas possessões, deveriam apresentálos à Fiscalização Bancária do Banco do Brasil, dentro do prazo, que a mesma fixasse, para efeito do julgamento da legitimidade de desses documentos e da cobertura cambial, dependendo de autorização daquela o fechamento do câmbio para a liquidação. A liquidação de modo diferente efetuada equiparar-se-ia a operação ilegitima, nos termos do art. 1 do decr. n. 23.258, de 19 de outubro de 1933, incorrendo os operadores nas penalidades do art. 6 deste decreto, que reprimiu o jogo sobre o câmbio. 